\title{
КИНО
}

UDC 791.2

\section{Dziga Vertov - Boris Kaufman - Jean Vigo}

\author{
E. A. Artemeva \\ Mari State University, \\ 1, Lenina pl., Yoshkar-Ola, 424000, Russian Federation
}

For citation: Artemeva, Ekaterina. "Dziga Vertov - Boris Kaufman - Jean Vigo". Vestnik of Saint Petersburg University. Arts 10, no. 4 (2020): 560-570. https://doi.org/10.21638/spbu15.2020.402

The article is an attempt to discuss Dziga Vertov's influence on French filmmakers, in particular on Jean Vigo. This influence may have resulted from Vertov's younger brother, Boris Kaufman, who worked in France in the 1920s - 1930s and was the cinematographer for all of Vigo's films. This brother-brother relationship contributed to an important circulation of avant-garde ideas, cutting-edge cinematic techniques, and material objects across Europe. The brothers were in touch primarily by correspondence. According to Boris Kaufman, during his early career in France, he received instructions from his more experienced brothers, Dziga Vertov and Mikhail Kaufman, who remained in the Soviet Union. In addition, Vertov intended to make his younger brother become a French kinok. Also, À propos de Nice, Vigo's and Kaufman's first and most "vertovian" film, was shot with the movable hand camera Kinamo sent by Vertov to his brother. As a result, this French "symphony of a Metropolis" as well as other films by Vigo may contain references to Dziga Vertov's and Mikhail Kaufman's The Man with a Movie Camera based on framing and editing. In this perspective, the research deals with transnational film circulations appealing to the example of the impact of Russian avant-garde cinema on Jean Vigo's films.

Keywords: Soviet cinema, French cinema, documentary cinema, cultural transfer studies, film studies.

In the 1920s, Soviet cinema flourished and attracted the attention of the artistic world by its innovative formalist theories and practices. At that time, Dziga Vertov's theory of Kinoglaz (Cinema Eye) captured the minds of young European documentary filmmakers. In particular, Vertov influenced the French filmmaker Jean Vigo who collaborated with cinematographer Boris Kaufman, Vertov's younger brother, on all his films. In this per-

(C) Санкт-Петербургский государственный университет, 2020 
spective, the research deals with transnational film circulations that speak to the example of the impact of Russian avant-garde cinema on Vigo's films.

The corpus of sources to be researched is vast, since it includes textual, iconographic, and cinematographic documents, produced in French and Russian, at various historical periods. The research takes into account the reading of sources on the avant-garde Soviet cinema, the Russian films that Vigo could view, and the manifestos that he could know (in particular, those of Dziga Vertov). This article is also based on the unpublished letters by Vertov, Mikhail Kaufman, and Boris Kaufman that can be found at the Russian State Archive of Literature and Art in Moscow [I].

The subject of study fits perfectly into the study of transnational circulations in the field of cinema, which, as Patricia-Laure Thivat points out, "throughout its history and up to the present day, has been teeming with examples of encounters, confrontations and / or cultural hybridizations" [1, p.11]. According to Michael Werner, the study of cultural transfers aims to describe "the interactions between cultures and societies in their historical dynamics", "to report on the conditions which marked their initiation and development" and "to analyze the phenomena of transmission, diffusion, reception, and reinterpretation" [2, p. 1190]. This conception is closely linked to Pascal Ory's idea that the cultural history is always "the social history of representations" [3, p. 68]. Thus, it is also important to characterize the French context of socio-cultural reception to attribute a place to the mentioned cinematographic works in the history of art and culture of the considered periods. Furthermore, it is appropriate to question if Vigo was influenced by Soviet film theories and practices (especially those of Vertov) and through what channels, direct and indirect, this influence could be exerted on him. The final step in the analysis is to examine the Soviet cinema and Vigo's films to discuss the affinity between their visual languages. The many influences and multiple inspirations constitute the power of cinema. However, being inspired by someone's work does not mean copying it. By proposing that "when a book, a theory, an aesthetic tendency cross the border between two cultural spaces $\langle\ldots\rangle$, their meaning, linked to the context, thereby changes" [4, p. 28], Michel Espagne develops the idea of a cultural transmutation. The filmmaker attributed a new meaning to the references, and this made the creation of a unique style possible. As a result, this research questions how individuals, ideas, and material objects go back and forth, how they move through borders.

Vigo belongs to the generation of filmmakers who started their film career in the great documentary wave known as the third avant-garde cinema which lasted from 1927 to 1930, according to the chronology of Richard Abel [5]. Historians agree on the significance of the great Soviets' influence on the third avant-garde, although their films were not sufficiently accessible outside the USSR ${ }^{1}$. For example, Barthélémy Amengale also stresses that "the third avant-garde was undoubtedly the heir of Vertov's Kinoglaz and of the early Soviet cinema considered as a whole" [7, p. 165]. Indeed, in one of his few interviews, Vigo recalled how he made his debut in cinema with $A$ propos de Nice: "Do you know how I started my career in cinema? I got sick and had to stay in Nice for long. $<\ldots>$ Then it was my first film. A documentary, about Nice. I succeeded thanks to the precious help of my excellent cameraman Boris Kaufman, the brother of Russian filmmaker Dziga-Vertoff" [8,

${ }^{1}$ Valérie Pozner recalls that, at the time in France, the presentation of Soviet cinema on French screens was rather weak (barely forty films) [6, p. 275]. 
p. 102 $]^{2}$. By pointing out that Boris Kaufman was Vertov's younger brother, Vigo believed that he gave the best possible recommendation to his cameraman, as the Soviet filmmaker was an authority for European pioneers of social documentary filmmaking.

Having a reputation as a communist sympathizer, Vigo was interested in Soviet films ${ }^{3}$, including Vertov's The Man with a Movie Camera, and he collaborated on all his films with Vertov's brother whose previous training as a filmmaker was influenced by Kinoglaz's ideas. In one of his rare interviews, Boris Kaufman said: "I decided, perhaps under Dziga's influence, to debut in cinema. During all this time [the end of the 1920s], I maintained contact with my brothers in Moscow. I would constantly watch for their work and immediately see their films as they arrived in Paris" $[10, \mathrm{p} .3]^{4}$. This close family relationship is mentioned in Mikhail's and Boris's correspondence of the 1960s $-1970 \mathrm{~s}^{5}$. Boris Kauffman wrote to Mikhail on March 3, 1968: "Your work does not make it here, I have seen nothing since I saw Spring. In Paris, I looked for your work, it lives vividly in my memory" [II, sh. 5] ${ }^{6}$. In the letter dated December 8, 1973, he recalled: "You know, I still remember your criticism and advice on my first works in Paris and your acute analysis of their naive mistakes. It was very useful" [II, sh. 9 $]^{7}$. In 1974 Boris received Mikhail's answer: "A propos de Nice which you shot with Vigo was promised to me, I have heard much praise about it $\langle\ldots\rangle$. I am sure that your contribution to motion picture art is great $\langle\ldots\rangle$. Your early Parisian works were very convincing of this fact. I have been long been proud of you" [I, sh. 3 $]^{8}$. Although Paulo Emilio Salès Gomès is not sure that Boris Kaufman is Vertov's brother", he also admits the impact of the Russian documentary school on the young cinematographer: "Boris is perhaps the third Kaufman brother, the youngest,

2 "Savez-vous comment je suis venu au cinéma? Malade, je fis un long séjour à Nice. <...> Puis ce fut mon premier film. Un documentaire: À propos de Nice. Je le réussis grâce à l'aide précieuse de mon excellent cameraman Boris Kaufman, le frère du cinéaste russe Dziga-Vertoff”.

3 According to the program of the Cinema club Les Amis du cinéma, which Vigo hosted in Nice, he saw at least six Soviet films: Eisenstein's Battleship Potemkin and The General Line, Trauberg's and Kozintsev's The New Babylon, Turin's Turksib, Pudovkin's The End of St. Petersburg, Protazanov's St. Jorgen's Day. Besides, we also know that in 1930, Vigo saw Dovzhenko's Earth and Dziga Vertov's The Man with a Movie Camera $[9$, p. 142-3].

4 "J'ai décidé, peut-être sous l'influence de Dziga, de me lancer dans le domaine du cinéma. <...> Pendant tout ce temps, je suis resté en contact avec mes frères à Moscou. Je suivais leur travail et je voyais immédiatement leurs films qui arrivaient à Paris".

${ }_{6}^{5}$ Dziga Vertov died in 1954.

6 "Tvoia rabota siuda ne prikhodit, ia nichego ne videl s 'Vesny'. V Parizhe ia sledil za tvoei rabotoi, ona rezko zhivet $\mathrm{v}$ moei pamiati".

7 "Ty znaesh', ia eshche seichas pomniu tvoi sovety-kritiku moikh pervykh rabot v Parizhe i tvoi pronitsatel'nyi analiz ikh naivnykh oshibok. Eto bylo ochen' polezno".

8 "Mne obeshchali skoro pokazat' tvoiu 'Nitstsu', kotoruiu ty snimal s Vigo, i o kotoroi ia naslyshan kak o zamechatel'nom proizvedenii iskusstva... Ia uveren, chto tvoi vklad $\mathrm{v}$ kinoiskusstvo ochen' velik... V etom menia ubezhdali i rannie tvoi raboty v Parizhe. Ia uzhe davno gorzhus' toboi".

9 Paulo Emilio Salès Gomès did not succeed in communicating with Boris Kaufman - who was a very reserved person - to know exactly if he was Dziga Vertov's brother. Bernard Eisenschitz explains, that "it is not without reason: in the 1940s and 1950s, to confess a brother on the other side of the Iron Curtain was dangerous in the United States (where he worked then) as in the USSR" [9, p. 145]. So, to get Oscar in 1954, Boris Kaufman lied about the fact that he did not have close parents in USSR. Boris Kaufman was so reserved as even the definite date of its birth is not known. But Jean Rouch recalls some details of Boris Kaufman's biography: "From 1925, people sense that the big dream is finished. The mother of the brothers Kaufman (Vertov has two brothers: Mikhail, the man with a movie camera, and Boris who works in France with Jean Vigo, then leaves for the United States) wants that one of three children at least is saved. She sends Boris in France where he studies mathematics" [IV, p. 123]. 
but it is also possible that Vigo and Kaufman deliberately created a myth. Anyway, Boris Kaufman seems to have indeed acquired his knowledge of cinema in the Soviet Union, and he did it through an association with the Kino-Pravda group" [11, p.55]. Moreover, according to the German documentary film Operator Kaufman by Rasmus Gerlach, Vertov wanted Boris Kaufman to sow his ideas, related to cinema, in France: "Dziga brought a present to his younger brother Boris, a small movable hand camera, a Kinamo <... A brother from Moscow wanted Boris to make a kinoki ${ }^{10}$ branch in France" [III]. Furthermore, in 1929 and 1931, Vertov visited France as part of his European tours. These travels were dedicated to the screenings of his films accompanied by lectures on the theory of Kinoglaz, which the French newspapers published several articles about. In addition, French film critic Léon Moussinac presented Vertov's theory as an already well-known documentary school: he called the transcript of his lecture The School of cinema [12, p. 4]. Some historians believe that it was Boris Kaufman who ensured the dissemination of Vertov's ideas among the French avant-garde. Guy Gauthier stresses that "Vertov owes part of his influence to the vogue for Soviet cinema thanks to Léon Moussinac, but especially to his brother Boris Kaufman, who had emigrated to France" [13, p. 61]. As Jean Rouch confirms, Boris Kaufman presented Vertovs' theories to his friends: "I met Boris Kaufman in the United States, he told me that it was at the terrace of Le Dôme where he read (Jean Lods, Henri Storck, Jean Vigo) the manifestos of the kinoki to his friends" [IV, p. 123] ${ }^{11}$. Thus, Vigo could also draw inspiration from Vertovs' ideas, and Kinoglaz could influence the image and the social message of the first documentary of Vigo and Boris Kaufman A propos de Nice, shot with Vertov's camera, as well as the visual aspects of their three following films: Jean Taris: Swimming Champion, Zero for Conduct, and L'Atalante, which is known to be the result of an evolution of the cinematographic language of Vigo towards poetic realism. Also, several historians claim that some allusions to other cinematographic techniques of Soviet origin can be clearly observed in his films ${ }^{12}$.

According to Kinoglaz, in the filmmaking process there is one major actor: the camera's lens that is supposed to be a multifunctional "mechanical eye", more powerful than a human one. In one of his manifestos, Vertov claimed: "I am a kino-eye, I am a mechanical eye. It is ' $I$ ' that is a machine, it shows you the world in the way that only I can see it. Now and forever, I free myself from human immobility, I am in constant motion, I draw near, then away from objects, I crawl under, I climb onto them. $<\ldots>$ free of the limits of time and space, I put any given points in the universe together, no matter where I've recorded them. $\langle\ldots\rangle$ I decipher a world unknown to you in a new way" [15, p. 17]. Like Vertov, in his presentation of A propos de Nice, Vigo expresses that "in the realm to be explored, the camera is the king or, at least, the President of the Republic" [16, p. 22] by stressing the importance of innovative framing techniques. They both wrote about intention "to film life unawares". According to Vertov, his documentaries aimed "to show people without masks, without makeup, to catch them through the camera eye in a moment when they are not acting, to read their thoughts, laid bare by the camera" [15, p.41], and Vigo and Boris Kaufman seemed to follow his instructions: "The camera should be directed at

${ }^{10}$ Dziga Vertov constructed the term kinok (plural kinoki) to distinguish his followers.

11 "J'ai rencontré Boris Kaufman aux Etats-Unis, il m’a raconté que ceétait à la terrasse du Dôme qu'il lisait à ses copains (Jean Lods, Henri Storck, Jean Vigo) les manifestes des kinoki”.

12 Barthélemy Amengual counts them as "rhetorical montage, Kino-Eye, eccentrism, sense of the setting, mainly outdoors, collective adventures without dramatic intrigue or hero" [14, p. 86]. 
something which must be recognized as a document, and which during the actual editing must be approached as such. Conscious posing or acting cannot be tolerated. Unless the character is taken unawares by the camera, the documentary value of this kind of cinema is impossible to attain" [16, p. 22]. That is how Paulo Emilio Salès Gomès evokes the shooting of A propos de Nice: "To catch strollers unawares, Vigo and Kaufman built a cardboard box to conceal the camera, and frequently went hunting. Their trophies were splendid: lots of ladies with parasols; bearded old men, bold men, one with a monocle reading a paper; several women, one of whom was superb, 'super-beastly', as Vigo described her in his notes..." [11, p.58]. Finally, what also unites Vertov's and Vigo's movies is the social message. Vertov made a movie on the routine life of Soviet workers, while Vigo created a pamphlet about the bourgeoisie of Nice. In that regard, A propos de Nice was very different from other French films of the late 1920s. François Albera thinks that in A propos de Nice Vigo "compares in a very Soviet way poverty and wealth, idleness and working, ending on close-ups delighted by workers in a foundry who return in nothingness carnival and its pretenses" [17, p. 114]. In his presentation of $A$ propos de Nice, following Vertov's social message, Vigo defines the film as "a documentary point of view", "social documentary" which "is distinct from the ordinary short film and the weekly newsreel in that its creator will establish his point of view: he will dot his own 'i's" [16, p. 23].

In 1929, Vigo prepared to shoot his first film and he needed the assistance of someone who mastered the techniques of cinema. This corresponds to what the writer Claude Aveline, who was Vigo's close friend at the time, described: "He dreamed about cinema, but he had neither the physical possibility nor the material resources" $[18, \text { p. 364 }]^{13}$. Vigo was not only looking for a cameraman, but he was also looking for a real collaborator. And Boris Kaufman became that person: "Since I didn't know Nice, he invited me to come there to write the script with him" $[19, \text { p. 5 }]^{14}$. Moreover, according to the contract from 7 March 1930, Boris Kaufman can be considered a true co-author of A propos de Nice: the film was made "in a total collaboration" and it is an "artistic property of each of two directors" [20, p.62]. However, given all these particularities and the visual aspect of the film, François Albera assumes that "this film owes as much, if not more, to Kaufman than to Vigo: it is a cinematographer's movie, the one of the man with a movie camera" [17, p. 114]. This bold hypothesis is based on the visual analysis of A propos de Nice, its images are captured in a way too refined for a debutant. Claude Aveline also raised the question of the "material resources" that Vigo did not have at the time. Boris Kaufman helps him to solve this technical problem: "I shot A propos de Nice by the Kinamo that Vertov gave me during his first visit to Paris" [10, p. 3 $]^{15}$. In fact, Boris Kaufman is one of the first ${ }^{16}$ who used a handheld $35 \mathrm{~mm}$ Kinamo in France, which is perfectly adapted to the exterior shots that Dziga and Mikhail Kaufman also practiced during the filming of The Man with a Movie Camera ${ }^{17}$.

\footnotetext{
13 "Il rêvait du cinéma, mais il n’avait ni la possibilité physique ni les moyens matériels".

14 "Comme je ne connaissais pas Nice, il m’invita à venir là-bas pour explorer et écrire le scénario avec lui".

15 "J'ai tourné À propos de Nice avec la Kinamo que Dziga Vertov mavait offerte lors de sa première visite à Paris".

16 As Thomas Waugh notes, "Boris Kaufman was one of the first to exploit the possibilities of this camera in France" [21, p. 70].

17 The importance of Kinamo camera in the non-commercial documentary filmmaking of the late silent period was significant as it permitted the filmmakers to shoot outdoors with a needed mobility and
} 
First of all, it should be noted that Vigo and Boris Kaufman continued the tradition of "urban films", which has been increasing since the early 1920s. At the end of that decade, there were already Alberto Cavalcanti's Rien Que Les Heures (1926), André Sauvage's Etudes sur Paris (1928), Walter Ruttmann's Berlin: Symphony of a Metropolis (1927), Dziga Vertov's The Man with a Movie Camera (1928), and Adalberto Kemeny's São Paulo, Sinfonia da Metrópole (1929). A propos de Nice is, therefore, a part of this well-established urban fashion in avant-garde cinema. It is, however, necessary to note that the Soviet documentary occupies a special place in the list of "symphonies of a Metropolis" because of the remarkable influence of Vertov's theory which began to spread before The Man with a Movie Camera was shot. Apparently, in making his Berlin, symphony of a Metropolis, Walter Rutmann, for example, followed Vertov's methods. To a certain extent, Vigo's L'Atalante fits into this tradition because there are several urban scenes, but it is not the Paris of postcards that was captured by Boris Kaufman's camera. The only tourist site that appeared in L'Atalante is the canal Saint-Martin. In general, we only see images of suburbs that are not very identifiable. It is rather a general overview of an industrial city, which refers to The Man with a Movie Camera, where Vertov represents the city by mounting the unrecognizable images of Moscow, Odessa, Kyiv, and Kharkov.

According to Paulo Emílio Salès Gomès, Vigo, "an admirer of the Russian films made under the NEP period of Soviet filmmaking, had always thought of using montage-attraction and the Kino-Eye techniques in some sequences" [11, p.63]. In addition to the cinematographic techniques, such as the superimposition, the time-lapse photography, the slow motion, and the reverse motion that the French cinema has known since its birth, The Man with a Movie Camera and A propos de Nice have really much in common. Some of Vigo's plans correspond to Vertov's camera angle as well as that of Alexander Rodchenko, who claimed in 1927: "The most interesting angles of view for contemporary photography is from top to bottom or from bottom to top and their diagonals" [22, p. 39] ${ }^{18}$. The total high-angle and low-angle shots and the use of geometric elements that accentuate the dynamism of the image became features of Alexander Rodchenko's style, which is aesthetically very similar to Vertov's (fig. 1,2).

Moreover, both Vertov and Vigo practice actively breaking of the fourth wall (fig. 3, 4). In The Man with a Movie Camera this technique reaffirms the presence of the man with a movie camera as a subjective entity. This one becomes a character, and to a certain extent, gets included in the everyday rhythm of the city with its routine. Obviously, in breaking the fourth wall in A propos de Nice and L'Atalante, Jean Vigo also let his cameraman enter the filmic space.

Next, Boris Kaufman's camera looks for unusual ways to combine objects with the background. For example, in one of the scenes, the gestures of the puppets reflected in the window and the movements of the Parisians are synchronous (fig. 5). In another sequence, the thief and the policemen are filmed through the iron fence. This decision made the image both dynamic and metaphorical. The kinoki Mikhail Kaufman and Alexander Rodchenko created a visual dynamism in the same way.

spontaneity. As is known, Dziga Vertov used this camera, and in the Austrian Film Museum there is a rare photo of Dziga Vertov holding his Kinamo [V].

18 "I samymi interesnymi tochkami sovremennosti iavliaiutsia tochki sverkhu vniz i snizu vverkh i ikh diagonali". 


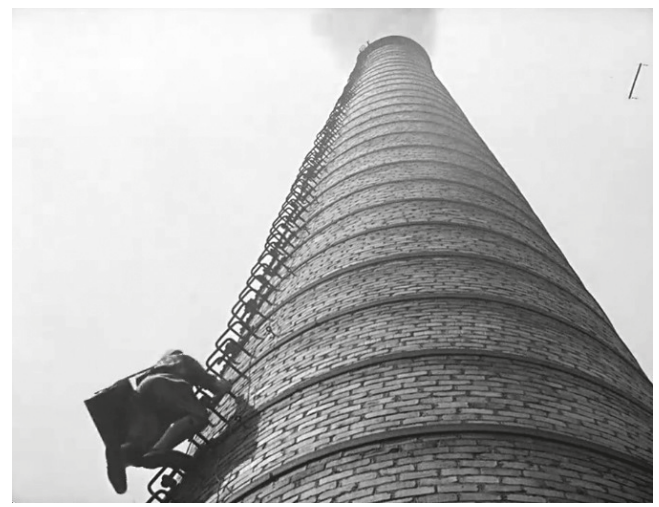

Fig. 1. The Man with a Movie Camera, directed by Dziga Vertov (1929; Paris: Arte vidéo: Scerèn, 2003), DVD

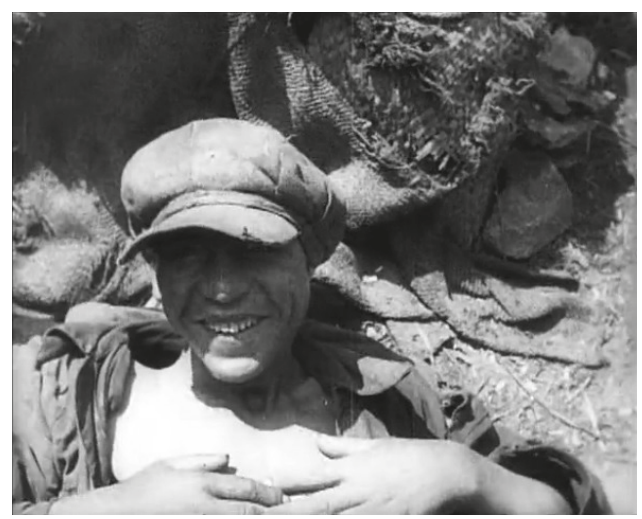

Fig. 3. The Man with a Movie Camera, directed by Dziga Vertov (1929; Paris: Arte vidéo: Scerèn, 2003), DVD

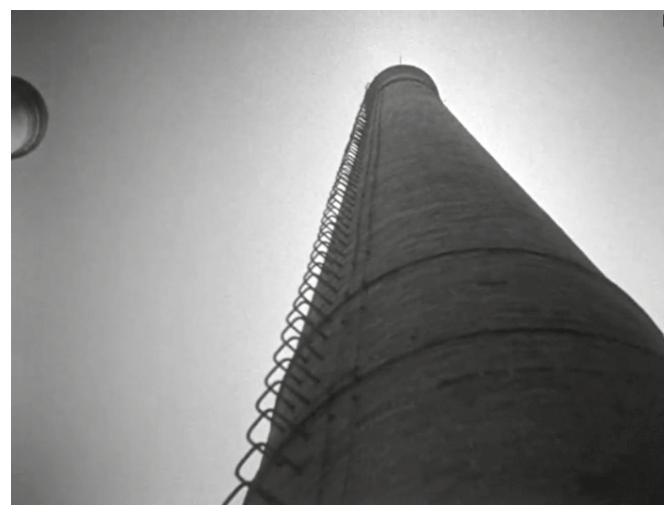

Fig. 2. A propos de Nice, directed by Jean Vigo and Boris Kaufman (1930; Paris: Gaumont, 2001), DVD

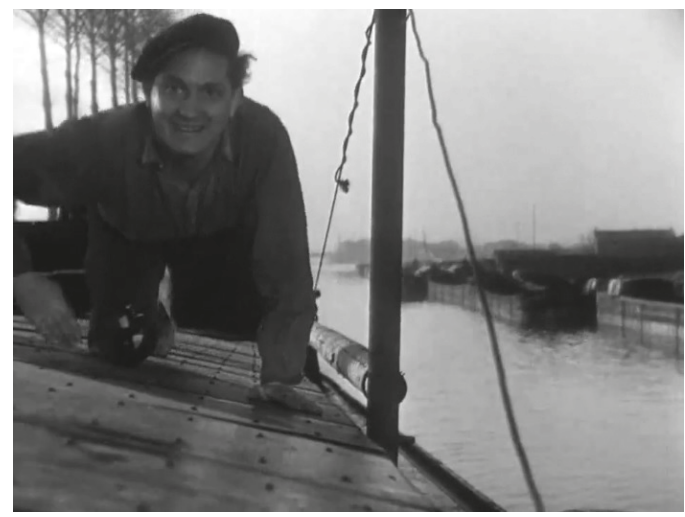

Fig. 4. The improvised shot from L'Atalante created the sense of an authorial presence of a cameraman holding the camera. L'Atalante, directed by Jean Vigo (1934; Paris: Gaumont, 2001), DVD

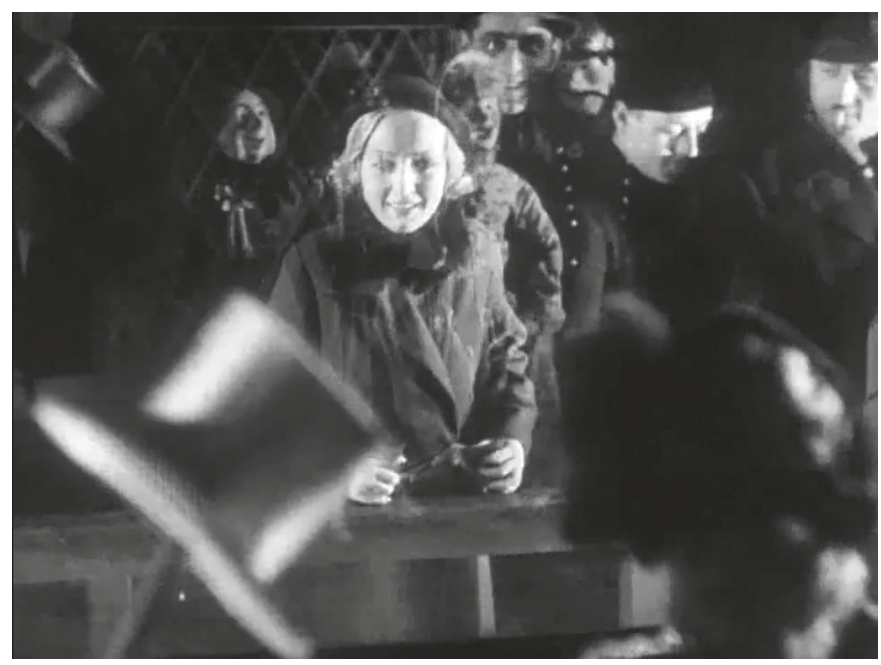

Fig. 5. L'Atalante, directed by Jean Vigo (1934; Paris: Gaumont, 2001), DVD 


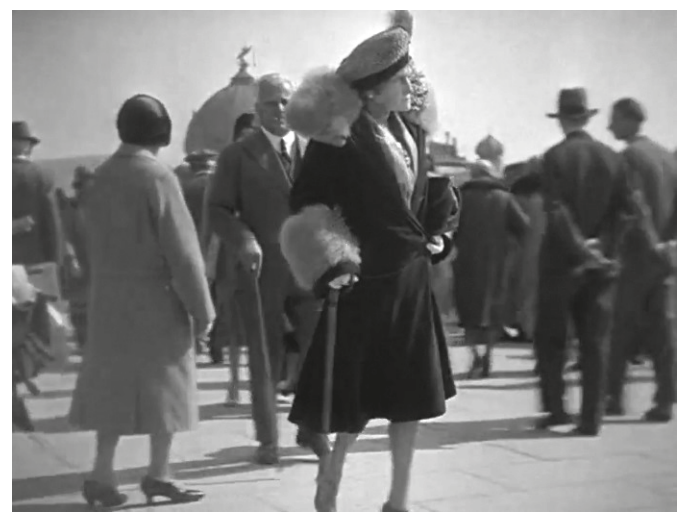

Fig. 6. A propos de Nice, directed by Jean Vigo and Boris Kaufman (1930; Paris: Gaumont, 2001), DVD

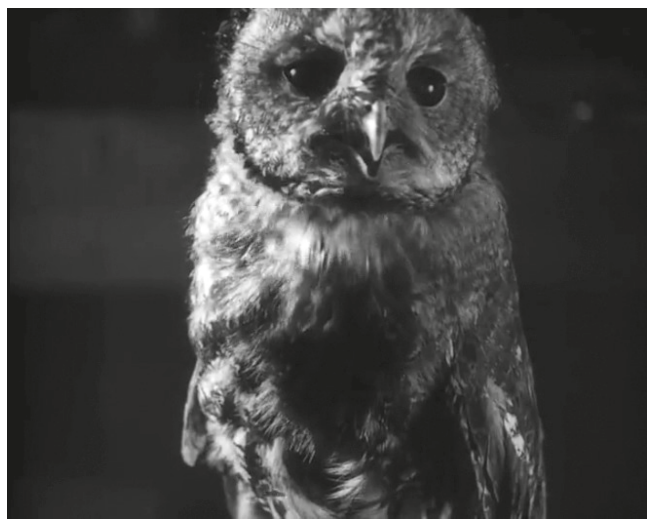

Fig. 8. Strike, directed by Sergei Eisenstein (1925; Paris: Carlotta Films, 2008), DVD

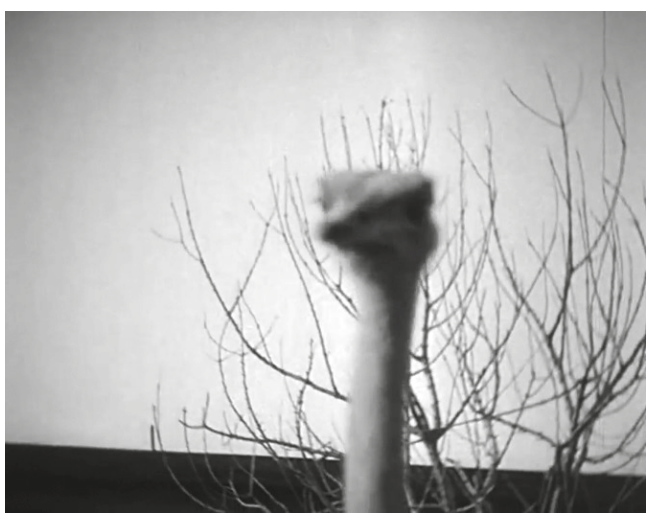

Fig. 7. A propos de Nice, directed by Jean Vigo and Boris Kaufman (1930; Paris: Gaumont, 2001), DVD

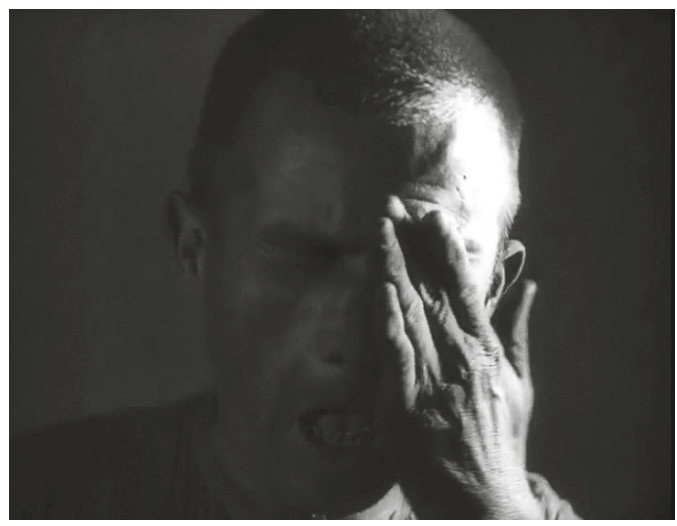

Fig. 9. Strike, directed by Sergei Eisenstein (1925; Paris: Carlotta Films, 2008), DVD

Vigo rhymes correlating sequences as do Sergei Eisenstein and Vertov. In A propos de Nice, a woman turns her head and, in the following sequence, an ostrich does the same (fig. 6, 7); in Strike, Eisenstein juxtaposes animals and persons in the same way (fig. 8, 9); in The Man with a Movie Camera, Vertov correlates the shot of sharpening of an ax and that of the shaving by a barber as two images of work. In the juxtaposition of these sequences, we can see the intention to build the filmic structure of the "cine-poem". As Noureddine Ghali points out, "among the Soviets, editing has become a system; they have made it the nerve of cinematographic practice, without which there is no valid film" [23, p. 181], while during the 1920s, the research of French filmmakers in the field of editing obviously lacks a systematic approach. According to Ghali, it is the Soviets that connect sequences by the associative montage bringing together several visual motifs (fig. 10-13). Nevertheless, A propos de Nice stands out from other French or Soviet urban documentaries of its time by its high conceptuality. Vigo's associative editing is based primarily on contrasts between luxury and poverty, idleness and work, youth and age, and life and death. The debutant filmmakers explained their film in the press-release in the following antithesis: 


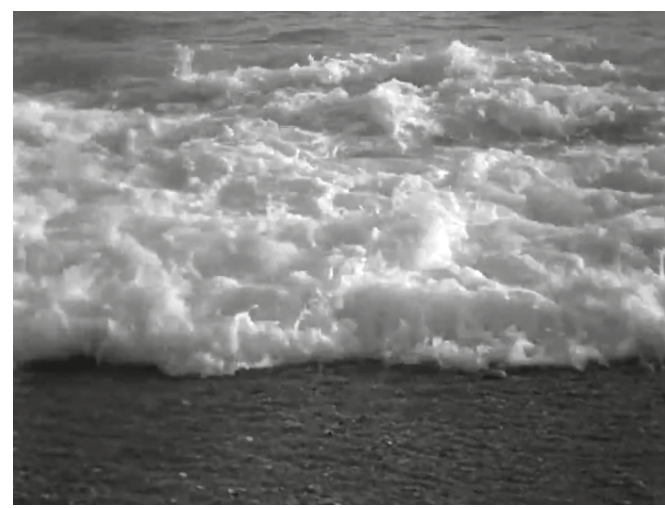

Fig. 10. Like Vertov, Jean Vigo created a dynamic visual rhythm by repeating and juxtaposing images that had some similar elements. A propos de Nice, DVD

directed by Jean Vigo and Boris Kaufman (1930; Paris: Gaumont, 2001), DVD

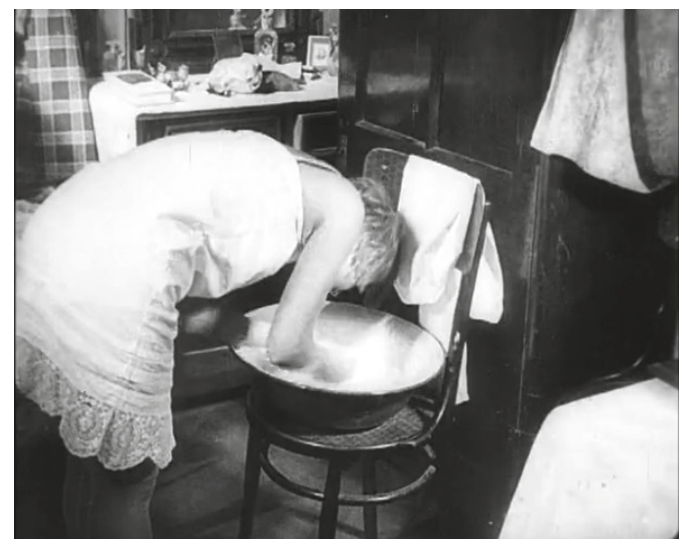

Fig. 12. The Man with a Movie Camera, directed by Dziga Vertov (1929; Paris: Arte vidéo: Scerèn, 2003), DVD

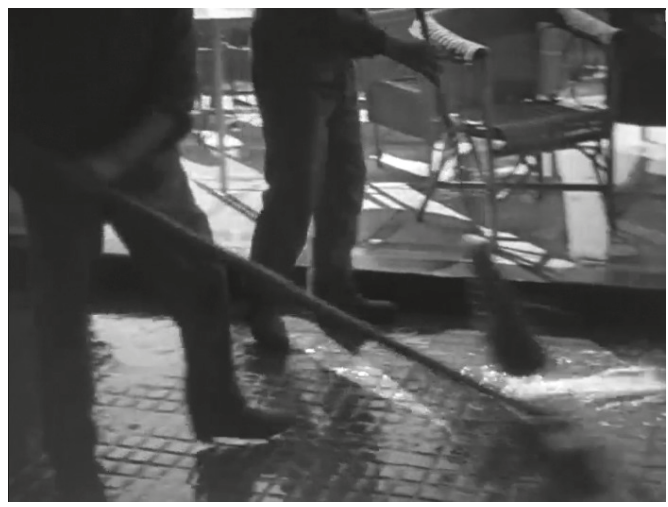

Fig. 11. A propos de Nice, directed by Jean Vigo and Boris Kaufman (1930; Paris: Gaumont, 2001),

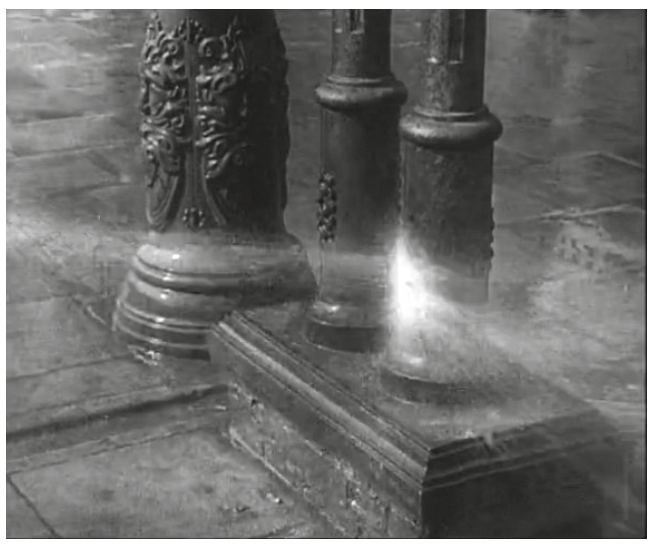

Fig. 13. The Man with a Movie Camera, directed by Dziga Vertov (1929; Paris: Arte vidéo: Scerèn, 2003), DVD

"Blue sky, white houses, bedazzled sea, sunshine, multicoloured flowers, hearts full of joy, such would appear at first the atmosphere of Nice. But this is only the ephemeral and transient appearance of a city of pleasures watched by death" [24, p.20].

Finally, Vigo also experimented with temporality by preferring slow motion. It is possible that it was Vertov who inspired Vigo to apply it in the swimming shots of Jean Taris: Swimming Champion and L'Atalante, since the Soviet filmmaker was one of the first who used slow motion to film the sport. In particular, according to Bamchade Pourvali [VI], it was Walter Ruttmann who advised Leni Riefenstahl to see The Man with a Movie Camera so that she could learn how to film sports plans in slow motion. Although French cinema has known slow motion since its inception, it was Vertov who attributed a different meaning to this technique. That is, he founded a new tradition of editing the sports action shots that found its extension in Vigo's films. 
Although in the late 1920s the distribution of Soviet films in Europe was insignificant for political reasons, they seemed to occupy a special place in French film practice. It is notably Vertov's films that met the expectations of young filmmakers and, in particular, those of Vigo. To a certain extent, we can see that Vigo's films have the visual traces of avant-garde, which could be of Russian origin. However, as Michel Espagne underlines, "to transfer is not to transport, but rather to metamorphose completely, and the term cannot by any means be reduced to the poor and very banal question of cultural exchange" [25, p. 1]. Even if Vigo could draw inspiration from Soviet visual theories and practices, he rethought them to create his visual language. To think that the filmmaker followed cinematic trends of the epoch to which he belonged seems to be more logical, since his films contain the ideas very similar to those of Vertov: the ideas of the European avant-garde, documentary cinema, social (and socialist) reflections, as well as tendencies of realistic art. Given the limitations of the study, we were unable to elaborate on some important sources. It is necessary to continue developing certain areas of the research, in particular, those pertaining to the relations between Vertov, Mikhail Kaufman, and Boris Kaufman. In the future, it is, therefore, necessary to explore Boris Kaufman's archives at Yale University that contain Vertov's ${ }^{19}$ and Michail Kaufman's ${ }^{20}$ unpublished letters addressed to his younger brother around 1945-1977, to shed light on unknown aspects of their cinematic relationships.

\section{References}

1. Thivat, Patricia-Laure, éd. Voyages et exils au cinéma. Rencontres de l'altérité. Villeneuve-d'Ascq: Presses Universitaires Septentrion, 2017.

2. Werner, Michael. "Transferts culturels". In Dictionnaires des sciences humaines, sous la direction de Sylvie Mesure et Patrick Savidan, 1189-92. Paris: PUF, 2006. (Dictionnaires Quadrige).

3. Ory, Pascal. "L'histoire culturelle de la France contemporaine: Question et questionnements". Vingtième Siècle. Revue d'histoire, no. 16 (1987): 67-82. https://doi.org/10.2307/3768734.

4. Espagne, Michel. Les transferts culturels franco-allemands. Paris: PUF, 1999. (Perspectives germaniques).

5. Abel, Richard. French Cinema: The First Wave, 1915-1929. Princeton, NJ: Princeton University Press, 1984.

6. Pozner, Valérie. “Moussinac et l'Union Soviétique (1927-1934): flux et reflux d'un engagement”. In Léon Moussinac, un intellectuel communiste, la direction de Valérie Vignaux, avec la collaboration de François Albera, préface de Pascal Ory, 267-310. Paris: AFRHC, 2014.

7. Amengual, Barthélémy. "Rapports entre le cinéma, la littérature et les arts en France dans les années vingt". Les cahiers de la cinémathèque, no. 33-34 (1981): 161-8.

8. Lherminier, Pierre. Jean Vigo. Paris: Pierre Lherminier, 1984. (Cinéma classique).

9. Eisenschitz, Bernard. "L'Atalante, film russe?" In "L'Atalante": un film de Jean Vigo, éd. par Nathalie Bourgeois, Bernard Bénoliel et Stéfani de Loppinot, 141-51. Paris: Cinémathèque Française, 2000.

10. Kagan, Simon. "Boris Kaufman, du documentaire à la fiction". Cahiers du cinéma, no. 331 (1982): 2-4, Le journal des cahiers, no. 20 : II.

11. Salès Gomès, Paulo Emílio. Jean Vigo. Oakland, CA: University of California Press, 1971.

12. Moussinac, Léon, "Lécole du Ciné-CEil". L'Humanité, juillet 27, 1929.

13. Gauthier, Guy. Un siècle de documentaires français: Des tourneurs de manivelle aux voltigeurs du multimédia. Paris: Armand Colin, 2004.

19 Yale Archives. Beinecke Rare Book and Manuscript Library. Boris Kaufman papers. Boris Kaufman Correspondenc. Dziga Vertov. 1947. Box: 14. Folder: 282. Call Number: GEN MSS 562.

20 Yale Archives. Beinecke Rare Book and Manuscript Library. Boris Kaufman papers. Boris Kaufman Correspondence. Mikhail Kaufman. 1945-77. Box: 13. Folder: 226. Call Number: GEN MSS 562. 
14. Amengual, Barthélemy. "Monde et vision du monde dans l’œuvre de Vigo". Études cinématographiques, no. 25 (1966): 49-87.

15. Michelson, Annette, ed. Kino-Eye: The Writings of Dziga-Vertov. Transl. by Kevin O'Brien. Berkeley; Los Angeles; London: University of California Press, 1984.

16. Vigo, Jean. "Toward a Social Cinema”. Transl. by Stuart Liebman. Millennium Film Journal 1, no. 1 (Winter 1977-78): 21-4.

17. Albera, François. L’Avant-garde au cinéma. Paris: Armand Colin, 2005.

18. Martin, Marcel. Jean Vigo. Paris: L’Avant-Scène Cinéma, 1966. (Anthologie du cinéma, t. 17).

19. Kaufman, Boris, "Un génie lucide: Jean Vigo". Ciné-Club, February, 1949.

20. Vigo, Jean. Euvre de cinéma: films, scénarios, projets de films, textes sur le cinéma. Paris: Pierre Lherminier, 1985. (Collection Cinéma classique).

21. Waugh, Thomas. The Conscience of Cinema: The Works of Joris Ivens, 1912-1989. Amsterdam: Amsterdam University Press, 2017.

22. Rodchenko, Alexander. "Ways of Modern Photography”. Novyi LEF, no. 9/21 (1928): 31-9.

23. Ghali, Nourreddine. L'Avant-garde cinématographique en France dans les années vingt: Idées, conceptions, théories. Paris: Paris expérimental, 1995.

24. Temple, Michael. Jean Vigo. Manchester: Manchester University Press, 2005. (French Film Directors).

25. Espagne, Michel. "La notion de transfert culturel". Revue Sciences / Lettres, no. 1 (2013). Accessed February 25,2019 . http://journals.openedition.org/rsl/219. https://doi.org/10.4000/rsl.219.

\section{Sources}

I. Russian State Archive of Literature and Art. Stock 2091. Record 95. (In Russian)

II. Russian State Archive of Literature and Art. Stock 2091. Record 105. (In Russian)

III. “Operator Kaufman by Rasmus Gerlach". Vimeo. Accessed April 16, 2019. https://vimeo.com/241351763.

IV. "Entretien avec Jean Rouch". In Devaux, Frédérique. L'homme à la caméra de Dziga Vertov, 121-4. Brussels: Edition Yellow Now, 1990.

V. Austrian Film Museum. Collection Dziga Vertov. V Pe 055.

VI. "L’Homme à la caméra de Dziga Vertov". Forum des Images. Accessed April 9, 2019. https://www. forumdesimages.fr/les-programmes/toutes-les-rencontres/lhomme-a-la-camera-de-dziga-vertov.

Received: September 4, 2019

Accepted: August 27, 2020

Author's information:

Ekaterina A. Artemeva — PhD, Associate Professor; artemeva_ea@marsu.ru

Для цитирования: Artemeva, Ekaterina. "Dziga Vertov - Boris Kaufman - Jean Vigo". Becтник Санкт-Петербургского университета. Искусствоведение 10, по. 4 (2020): 560-570.

https://doi.org/10.21638/spbu15.2020.402 